\title{
Contested natures: Coca, the War on Drugs, and ecologies of difference in Colombia's Afro-Pacific
}

\author{
Alexander Huezo ${ }^{1}$ \\ Florida International University, USA
}

\begin{abstract}
While there is growing consensus that the 'war on drugs' has failed to decrease drug consumption in the Global North, we know much less about how drug production has impacted communities of the Global South. This is particularly true for the cultivation of coca leaf in Colombia, which is increasingly planted in isolated rural areas such as national parks and in the collectively titled lands of ethnic communities (indigenous and Afrodescendant) where it is both difficult to detect and to eradicate. This article explains how Afro-descendant communities in Colombia have resisted both coca cultivation and a controversial war on drugs strategy to eliminate coca -aerial eradication - through a framework of ecological difference. It also explores why political ecologists can be important allies in this struggle and in the greater context of socio-environmental justice for rural communities in the Global South.
\end{abstract}

Key Words: rural, ethnic, difference, war, coca, Colombia

\section{Résumé}

Bien qu'un consensus se dégage sur le fait que la «guerre contre la drogue» n'a pas réussi à réduire la consommation de drogue dans le Nord, nous en savons beaucoup moins sur l'impact de la production de drogue sur les communautés du Sud. Cela est particulièrement vrai pour la culture de la feuille de coca en Colombie, qui est de plus en plus plantée dans des zones rurales isolées telles que les parcs nationaux et sur les terres de communautés ethniques (autochtones et d'ascendance africaine) où il est difficile de détecter éradiquer. Cet article explique comment les communautés de descendants d’Africains en Colombie ont résisté à la culture de la coca, ainsi qu’à la stratégie controversée de lutte contre la drogue pour éliminer la coca - l'éradication aérienne - à travers un cadre de différences écologiques. Il explore également pourquoi les écologistes politiques peuvent être des alliés importants dans cette lutte et dans le contexte plus large de la justice socio environnementale pour les communautés rurales des pays du Sud.

Mots-clés: rural, ethnique, différence, guerre, coca, Colombie

\section{Resumen}

Si bien hay un consenso creciente que la 'guerra contra las drogas' no ha logrado disminuir el consumo de las drogas en el Norte Global, pero sabemos mucho menos sobre cómo la producción de las drogas ha impactado a las comunidades del Sur Global. Esto es particularmente cierto en el caso del cultivo de hoja de coca en Colombia, que se planta cada vez más en áreas rurales aisladas, como los parques nacionales y en las tierras de comunidades étnicas (indígenas y afrodescendientes), tituladas colectivamente, donde es difícil de detectar y erradicar. Este artículo explica cómo las comunidades afrodescendientes en Colombia han resistido tanto el cultivo de coca como la estrategia de guerra contra las drogas para eliminar la coca (la fumigación aérea) a través de un marco de diferencia ecológica. También explora por qué los ecólogos políticos pueden ser aliados importantes en esta lucha y en el contexto más amplio de la justicia socioambiental para las comunidades rurales en el Sur Global.

Palabras claves: rural, étnico, diferencia, guerra, coca, Colombia

\footnotetext{
${ }^{1}$ Dr. Alexander Huezo, Department of Global and Sociocultural Studies, Florida International University, USA. Email: adhuezo "at" gmail.com. https://contestednatures.com/. Thank you to anonymous referees and funders: SSRC, New York and Florida International University.
} 


\section{Introduction}

On August 20, 2012, Colombian army helicopters and small planes used chemical warfare on the collective territory of the black communities of Alto Guapi.

As a result of this chemical warfare, the local residents say that Francisco Paz Cuenú, an 80-year old grandfather (who was in good health), immediately fell ill and passed away on August 21, 2012 at 4:00A.M., after being exposed to that damned fumigation poison. ${ }^{2}$

While there is growing consensus that the 'war on drugs' has failed to decrease drug consumption in the Global North, we know much less about how drug production has impacted socio-environmental justice in communities of the Global South. This is particularly true for the cultivation of coca leaf in Colombia, which is increasingly planted in isolated rural areas such as national parks and in the collectively titled lands of ethnic communities (indigenous and Afro-descendant) where it is both difficult to detect and to eradicate.

The fiery passage above is excerpted from an open letter in which a rural black community organization in the Pacific region of Colombia condemns aerial eradication, the strategy of using crop dusting aircraft to destroy illicit crops. Having previously conducted research on comunidades negras - rural black communities with collectively titled lands - and also the criminalization of coca cultivation in Colombia, I had a lot of questions about the strongly worded accusations in the letter. Why was aerial eradication permitted, especially considering that the Pacific region is largely occupied by two sets of ethnic minority populations -indigenous and Afro-descendants - that have supposedly earned the right to determine what happens within the boundaries of their respectively titled lands? Why does the letter paint the image of a Colombian armed forces intentionally waging chemical warfare on this particular community?

The main objective of this article is to describe how a 'political ecology of difference' (Escobar 2008) has been operationalized to challenge this particular aspect of the war on drugs in Colombia. Aerial eradication - regardless of one's perspectives about its efficacy or socio-environmental impacts - can be considered a failure because instead of working with communities and organizations that actively discourage the cultivation of coca, aerial eradication further alienates comunidades negras, and peasants in general, who are already distrustful of a Colombian state that has limited presence in rural parts of the country.

In presenting this strategy as a failure, I demonstrate three important ways political ecology can advance understandings of the war on drugs in general: 1) people and their traditions are part and parcel of the biodiversity endangered by drug production and counternarcotics efforts; 2) paying attention to culture also means paying attention to the internal struggles to preserve the ways of life endangered by drug production; and 3) political ecologists, especially those working closely with communities impacted by drug production and counternarcotics efforts, are uniquely situated to challenge the 'hierarchies of credibility' (Tate 2015) that determine drug policies.

In 2015 I conducted interviews and collected map data to investigate this controversy. Coincidentally, the aerial eradication program was suspended on the very same day I was scheduled to return home after ten months of fieldwork. I was immediately overjoyed as this decision suggested a shift away from a punitive stance on illicit crop cultivation to strategies that could provide better alternatives for poor farmers. After decades of US influence on this issue, it seemed as though the Colombian government was finally pivoting towards more progressive approaches to drug policy - with a greater emphasis on alternative development - as it negotiated a peace settlement with the Revolutionary Armed Forces of Colombia (FARC).

Unfortunately, however, this victory has been relatively short-lived. Since the suspension of aerial eradication coca cultivation has boomed in Colombia (The White House 2018), especially in the southwest corner of the country where I conducted interviews with residents of comunidades negras. The various groups that have replaced the FARC in two illicit economic activities - drug production and mining - are murdering

\footnotetext{
${ }^{2}$ Translation of letter penned by an Afro-descendant organization named Cococauca Guapi, Cauca. Author translated any texts, speeches and interviews in this article originally communicated in Spanish.
} 
community leaders and activists so frequently that human rights organizations are questioning the terms of recent the peace settlement (Human Rights Watch 2018). Meanwhile, the respective administrations of the outgoing president (Juan Manuel Santos) and recently inaugurated president (Iván Duque) both initiated steps towards reinstating aerial eradication, but this time with drones instead of crop-dusting planes. ${ }^{3}$ It is within this context, of continued violence in rural communities and monumental pressure to reinstate a controversial drug policy, which this article examines coca cultivation, aerial eradication, and ecologies of difference in Colombia.

\section{Contested natures}

'Contested natures' is an intentionally ambiguous term in this article's title. In the first place, the term signals political ecology as a form of critique meant to "disrupt normal expectations, undermine inherited assumptions," and which also acknowledges "the inevitable political roots of all environmental knowledge" (Robbins 2012: 98). Secondly, 'contested natures' implies that terms such as 'nature' or 'environment' or 'biodiversity' should be deconstructed in order "to open up the category of the environment itself and explore its multiform representations" (Peet and Watts 2004: 19). In the third place, 'contested natures' draws attention to the struggles for natural resources happening in rural Colombia, which entails the "the social, spatial and inter - temporal patterns of access to the benefits attainable from natural resources and from the environment as a life support system" (Martínez-Alier 2002: 73). These struggles not only consist of access to material resources such as food and water but also the traditions and practices that people have developed to sustain themselves in their environs. Therefore, in the fourth place, 'contested natures' connotes conflicting perspectives about what traditions or practices people define as part of their culture. In the case of comunidades negras of the Pacific region, these conflicting perspectives are both about the external perception of what happens in comunidades negras (e.g., "Coca, an illicit crop, is being cultivated in comunidades negras." and the internal struggle to define how life is carried out in comunidades negras (e.g., "Coca cultivation is not part of the cultural heritage of comunidades negras") In this regard, 'contested natures' refer to the central importance of culture in the theorization of nature and territory, an important attribute of Latin American political ecology (Porto Gonçalves and Leff 2012: 34). Lastly, 'contested natures' highlights disagreements about the ecological impacts of aerial eradication, many of which are debated in the Colombian judicial system.

The Process of Black Communities (PCN), an Afro-descendant organization at the forefront of the struggle to invest comunidades negras with territorial rights in Colombia, facilitated the vast majority of my visits to the Pacific region. This organization was instrumental to the implementation of Colombian Law 70 (created in 1993), which allowed for the recognition of collective land titles on the basis of an Afro-descendant identity rooted in the Pacific region's unique history, cultural traditions, and geography. However, while I knew the PCN viewed aerial eradication as a violation of the territorial rights they have been championing for, asking residents of comunidades negras their opinions about this strategy was a more delicate matter than I anticipated.

I conducted interviews in the communities surrounding the municipalities of Guapi and Buenaventura because I was advised that this was much safer than visiting heavily fumigated Tumaco (see Figure 1). Some of the residents I interviewed had cultivated coca, which meant that they were at least partially to blame when aerial eradication planes sprayed more than coca plants (i.e., subsistence crops, cash crops, waterways...etc.). What I encountered in many of these interviews, therefore, was two sets of complimentary performances developed from PCN's discussions of these problems: 1) the staunch objection to aerial eradication as a counternarcotics strategy initiated by a foreign government (the United States) and carried out by the Colombian counternarcotics police (DIRAN) and 2) the condemnation of coca cultivation as an economic activity alien to local agricultural traditions and largely conducted to satisfy foreign consumption (mainly, the United States).

\footnotetext{
${ }^{3}$ The rationale behind this latest push for aerial eradication is that drones are safer because human pilots are no longer in danger of being shot down and because the drones can fly lower than planes, minimizing the effects of wind that could blow the glyphosate onto food crops not meant to be sprayed (Felbab-Brown 2018). Despite these guarantees, aerial eradication continues to be a hotly debated topic in Colombia and amongst US-Colombian drug policy officials and critics.
} 


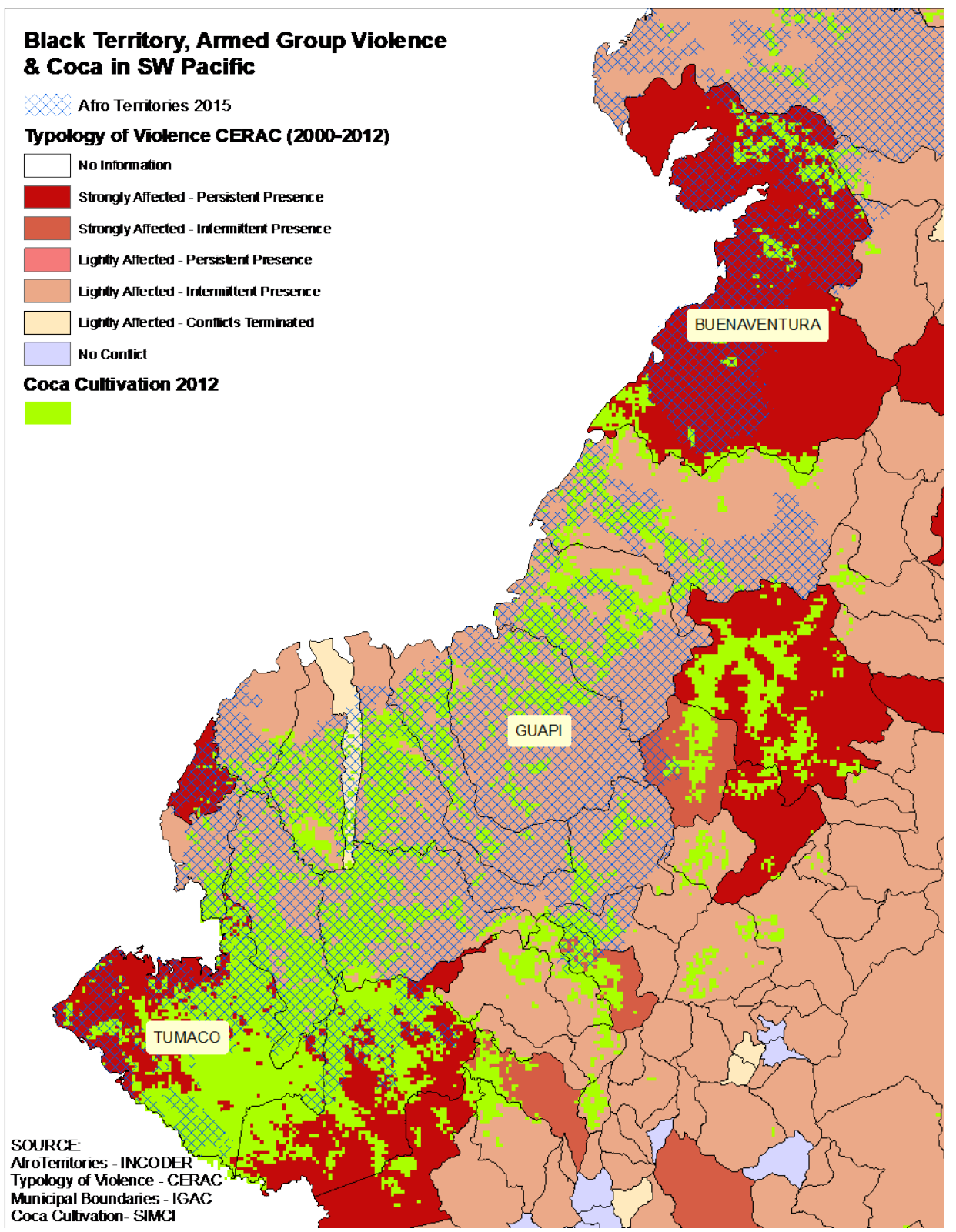

Figure 1: Comunidades Negras, Coca cultivation and violence in Southwestern Colombia. ${ }^{4}$ Source: Alexander Huezo

\section{A political ecology of difference}

The political ecology framework laid out by Colombian anthropologist Arturo Escobar, a longtime collaborator with PCN, is of fundamental importance to understanding these dual performances. Escobar, in conjunction with other Latin American political ecologists (Porto-Gonçalves and Leff 2012), issues a call for

\footnotetext{
${ }^{4}$ The Conflict Analysis Resource Center (CERAC) is a nonpartisan nongovernmental research center that specializes in the socio-economic impacts of conflict and violence in Colombia.
} 
political ecologists to move towards more locally contingent understandings of environmental issues by paying more attention to culture. What further sets apart this 'political ecology of difference' framework from other critical (Forsyth 2003; Robbins 2012) and place-based approaches to political ecology (Braun 2002; Ogden 2011 ) is that it is developed in collaboration with people - residents and activists of the Pacific region (such as the PCN) - normally excluded from participation in academic discourses. Thus "traditional production systems" such as fishing, hunting, and small-scale agriculture are "grounded in local models of nature...and an entire representational and cognitive universe that can be characterised in terms of economic, ecological, and cultural difference vis-à-vis the dominant Euro-Andean model" (Escobar 2003: 161).

Therefore the political ecology of difference operates both as a critique of top-down approaches to knowledge production and as a framework for the production of alternative forms of knowledge. Throughout this article I refer to discourses 'produced through the political ecology of difference', both to signal the origins of perspectives shaped by this collaborative framework and to highlight how comunidades negras "engage in the defense of place from the perspective of the economic, ecological, and cultural difference that their landscapes, cultures, and economies embody in relation to those of more dominant sectors of society" (Escobar 2008: 6).

One major critique of this framework it that it is so focused on the conceptualization of difference articulated through collaboration with PCN that it oversells the extent to which this political ecology of difference framework represents the politics of comunidades negras as a whole. Multiple scholars raised some version of this point in their reviews of Territories of difference (Escobar 2008); for instance, Routledge states that Escobar provides "an incomplete picture of the social movement in question" (2012: 144), while Sundberg writes that Escobar's theorization of difference via exteriority runs the risk of ignoring epistemological differences across borders throughout the Americas (ibid.: 145), and Power explains that Escobar's PCN focus leaves little room "to consider the politics of black Colombians who occupy other subject positions" (ibid.: 148).

Given the fact that PCN leaders facilitated my access to the vast majority of my interviews and observations in the southwestern Pacific, those same critiques could be applied to my own research. As a scholar newly establishing relationships with the various Afro-descendant organizations in the Pacific, I had not anticipated the extent to which local politics threaten the solidarity of comunidades negras and impact external perceptions of these communities. For instance, I mentioned wanting to meet with members of Regional Cococauca (another Afro-descendant organization) to a PCN leader during my first visit to Guapi and he immediately became less talkative. Sensing tension between the two organizations, I asked whether this meant I should choose which organization I wanted to work with during my fieldwork, at the risk of being ostracized by both. ${ }^{5}$ I later found out that consejos comunitarios (community councils) in Guapi were split between Regional Cococauca and PCN. ${ }^{6}$ This resulted in each side making decisions independently of the other council members, as if there were two different separate councils functioning in those communities. To the chagrin of some PCN leaders, such disagreements contributed to the outside perception that Afro-descendant organizations were not as unified as their ethnic minority counterparts, Indigenous Colombian organizations, which are more broadly connected under the umbrella of the National Indigenous Organization of Colombia (ONIC). ${ }^{7}$

While I agree that solely focusing on the PCN network paints an incomplete picture of the complex dynamics of social movements in the Afro-Pacific, such critiques seem to miss a greater point about the political ecology of difference framework. The Process of Black Communities (PCN) is engaged in an ongoing defense of a vulnerable population through community building, which requires various layers of collaboration. These efforts materialized at a critical juncture in Colombian history when the empowerment that Indigenous and

\footnotetext{
${ }^{5}$ Author interview with PCN leader at Cali airport on March 13, 2015. Ironically it was a letter from Regional Couca that sparked my interest in researching the impacts of aerial eradication in comunidades negras (see the introductory quote of this article).

${ }^{6}$ Oslender describes community councils of the Afro-Pacific as an "ambiguous organizational figure", partially because these councils embody the "formal recognition of local representational space" and partially because some of these councils have been co-opted by capital and the state (2016: 159).

${ }^{7}$ Author interviews with several PCN leaders during the week of March 13, 2015.
} 
Afro-descendants peoples experienced while organizing for recognition and rights under a new constitution in 1991 is, "...met with a forceful and brutal violence that is indelibly marked by the suppression of ethnic and cultural difference" (Escobar 2003: 160). The fact that other Afro-descendant organizations exist apart from the PCN and possibly in opposition to the PCN is vital context to understanding the region but less relevant to the articulation of defense theorized through the framework. Therefore, those dual performances - the objection to aerial eradication and the condemnation of coca cultivation - are presented as such throughout this article strategies employed with the intention of building consensus in comunidades negras but that do not presuppose consensus.

A second major critique of the political ecology of difference framework is that it essentializes the identity, culture and politics of comunidades negras as a population diametrically opposed to the outside world and the forces of modernity. For instance, Wainwright and Barnes problematize Escobar's conceptualization of 'nature', stating that it privileges an idea of 'place' that is useless unless defended by subaltern groups against the presupposition of an "overarching global project" (2009: 978). Likewise, Asher argues throughout Black and green: Afro-Colombians, development, and nature in the Pacific lowlands for a more nuanced understanding of black social movements in the Afro-Pacific, "through the case of black struggles in the Pacific lowlands, such alternatives are not simply outside or opposed to modernity; rather, the alternatives emerge from the relations between struggles and development" (2009: 189). Both assertions - the former a direct critique and the latter an indirect critique of the political ecology of difference - subordinate the practical value of articulating cultural difference (i.e., a means to unify a people as a community) in favor of more nuanced theorizations that avoid "being seduced by the romance of resistance and identity politics" (Asher and Wainwright 2019: 37). While "romance" is used pejoratively within the quote, a not so subtle dig at Escobar's framework, it should be noted that social movements require passionate conviction from their participants.

Nevertheless, this article contributes to the political ecology of difference literature by taking the above critiques seriously and conceptualizing difference not only as a challenge to dominant Euro-descended models of thought, but also as a struggle to achieve consensus within the ethnic minority communities articulating such challenges. While much of this literature focuses on how difference is articulated in resistance to external pressures or threats (Grueso et. al. 2003; Escobar 2003, 2008), issues like coca cultivation highlight the extent to which the aforementioned performances, particularly the condemnation of coca cultivation, are representative of an internal struggle to maintain community. For the PCN, an organization proud of a horizontal leadership structure that provides the space for open dialogue, working through such disagreements is part of the continual process of becoming comunidades negras.

\section{Aerial eradication as environmental conservation?}

As ironic as it might seem, US and Colombian aerial eradication authorities justify the aerial fumigation of illicit crops as a form of environmental conservation (Colombian National Police 2014; US Embassy Website). This discourse posits aerial eradication as the antidote to the much more damaging effects of cultivating coca as well as processing coca paste and consisted of three central arguments:

1. Coca growers destroy the environment by cutting down vegetation to clear land, using chemicals to cultivate coca, and using even more chemicals to process the coca into paste.

2. The chemical mixture sprayed during aerial eradication is really not that harmful (see Figure 2). Glyphosate, also known as Monsanto's Roundup, is the primary chemical used in the mixture. It is one of the most common herbicides in the world.

3. The perception that the aerial eradication chemicals are harmful is misguided because what really causes environmental harm are the chemicals used to cultivate and process coca, which seeped into the soil and waterways before any aerial eradication was conducted.

The following excerpt is from a US Embassy in Bogotá webpage entitled "Narcotic Affairs": 
What do the bad guys do? To plant coca, drug traffickers first go to a place and have to clear away forest or jungle, using fire, using chemicals, axes, whatever they have. They are the first to destroy the environment. Aerial fumigation will only destroy the coca, which is not a native plant in most places where it is planted and when they remove the coca, vegetation and forest, natural forest can grow back because glyphosate has no residues in the soil, which means that after one week there are no traces that glyphosate had ever been there because it converted into a very natural innate chemical, mostly nitrogen. ${ }^{8}$

DIRAN's publication Coca: deforestation, pollution and poverty echoes this sentiment; the book details how plots of tropical forest are burned and cleared for the establishment of coca fields, which require the application of pesticides, fungicides, herbicides (including glyphosate), and fertilizers that seep into the soil and waterways. The laboratories where the coca is processed into paste are normally adjacent to the fields and employ a long list of chemicals - such as gasoline, kerosene, ether, ammonia, hydrochloric acid and sulfuric acid - that also make their way into the soil and waterways (Colombia 2014: 138).

Thus, in the eyes of both US and Colombian eradication authorities, whatever potential damages brought on by aerial fumigation were negligible compared to the deforestation and the loss of biodiversity caused by the 80+ chemicals used in the cocaine production chain (US Embassy Website). DIRAN estimates that every hectare of coca cultivated causes 1.46 hectares of deforestation (Colombia 2015: 70).

\section{A biodiverse region}

US and Colombian drug policy officials described aerial eradication as a means to protect ethnic communities and their rights ${ }^{9}$, while many Afro-descendants understood aerial eradication as quite the opposite. Some PCN leaders went so far as to describe aerial eradication an intentional means of displacement, imposed by the Colombian government to satisfy both the US War on drugs and capitalist interests in the region. To explain this line of thinking - which may sound radical to those unfamiliar Colombia's long history of violent conflicts, especially the atrocities committed in rural Colombia - it is important to consider the environmental discourses that contributed to the collective titling of comunidades negras.

The PCN championed the formal recognition of comunidades negras by following the autochthonous model of territoriality established by indigenous communities throughout the Americas. This entailed the articulation of cultural difference tied to specific territories (Cárdenas 2012: 309), based on the following argument: comunidades negras originated in the Pacific region and have practiced cultural traditions unique to this space ever since the Spanish forcefully imported African slaves to work in goldmines. Furthermore, these communities have maintained a symbiotic relationship with their environment, noteworthy because the Pacific region contains huge swaths of tropical forest isolated from the rest of Colombia by the Andes Mountains.

\footnotetext{
${ }^{8}$ Author translation of text originally in Spanish. The author downloaded this webpage on July 28, 2015, and the webpage was removed from the US Embassy in Bogotá website later that year.

${ }^{9}$ Author interview with INL staff: Jorgan Andrews (Director), Ben Embury (Environmental Program Manager) David Walter (Eradication Program Manager), Bernardo Reina (Rule of Law Program Manager), Ingrid Simón (Scientific Officer) Kate Bentley (Press Attaché), Erin Truhler (Assistant Information Officer). Interview conducted at US Embassy in Bogotá on August 4, 2015. Author interview with Lieutenant Colonel Miguel Tunjano Villaraga of DIRAN, in charge of aerial eradication detection group. Interview conducted at Hotel Tequendama in Bogotá on May 8, 2015.
} 


\section{Glifosato}

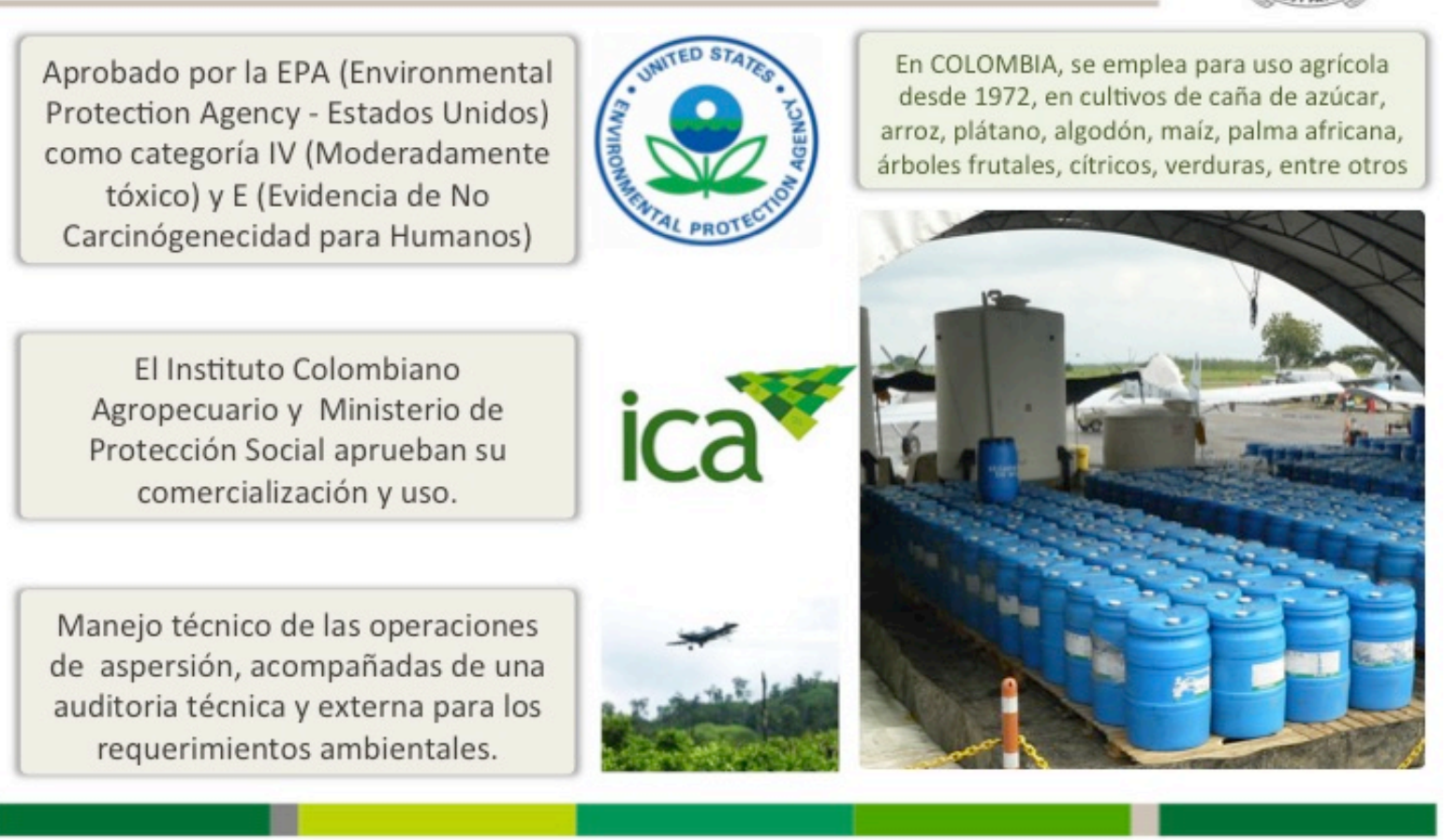

www.policia.gov.co

Figure 2: PowerPoint slide that provides details on glyphosate use in Colombia. The slide notes that the chemical is approved by the US Environmental Protection Agency as a "moderately toxic" substance with evidence that is it not carcinogenic for humans. (DIRAN website)

As is the trend elsewhere throughout the tropics, in the last thirty years scientists have labeled the Pacific region of Colombia a 'biodiversity hotspot' in need of conservation. State agencies and development-minded entities have reinforced this logic by articulating the need to protect a biodiverse, resource-rich region important to the advancement of the Colombian economy. According to this line of thinking, scientists should maximize the utility and profitability of the genetic material found within the Pacific region because biodiversity has become a "national resource" capable of generating enough wealth to lift Colombia out of its poverty (Restrepo 2013: 202). This push to conserve biodiversity, as Escobar points out, signifies an ontological shift away from the ecological sensibilities of comunidades negras: "From a discursive perspective, then, biodiversity does not exist in an absolute sense. Rather, it anchors a discourse that articulates a new relation between nature and society in global contexts of science, cultures, and economies" (1998: 55). Fellow Colombian anthropologist Restrepo explains, "Terms such as 'biodiversity', 'endemism', 'biological diversity', 'genetic resources', 'bioregion', virtually unheard not long ago, become referents of a different theoretical and political imagination of the region" (2013: 208). Comunidades negras and indigenous communities have taken issue with this particular imagination of the region's biodiversity because "the collective titling of ethnic lands, local participation, and the preservation of traditional knowledge of natural resource management became subsidiary goals of economic development and environmental conservation mandates" (Asher and Ojeda 2009: 294). 
In response to the marginalization of comunidades negras by such mandates, the PCN has promoted an alternative conceptualization of biodiversity articulated through a political ecology of difference. This alternative conceptualization is an important challenge to more commonplace understandings of biodiversity taken for granted not just in the Colombian Pacific, but throughout the world. While it is relatively easy to find academic literature about 'how humans affect biodiversity' (Adams et al. 2004; Dawson et al. 2011; Reid 1998; Myers and Mittermeier 2000) or about 'how the loss of biodiversity affects humans' (Blaikie and Jeanrenaud 1996; Díaz et al. 2006; Naem 2013), it is very rare to find articles about humans and human culture defined as elements of biodiversity.

Within the PCN framework, biodiversity signifies something far more than a resource to be simply extracted from the environment. In the course of my interview with PCN leader Benjamín Mosquera of Río Anchicayá, I asked him to comment on the relationship between biodiversity and territory. Benjamín countered that biodiversity is not something that exists separately from territory:

No, for us it is all part of the same thing because the territory is biodiversity and our culture. We do not separate territory from biodiversity because territory for us is the guarantee of existence. Apart from ourselves, biodiversity is what we have learned by virtue of coexisting with the territory. The biodiversity of species we have here forms part of the collective of life. Essentially we are that, everything existing together. And we defend biodiversity not because a species is becoming extinct but we do so because it affects the habitat, the entire ecosystem. ${ }^{10}$

Biodiversity, therefore, encompasses everything within the "collective of life", which includes the flora, fauna, and natural resources as well as the people inhabiting these spaces.

\section{Displacing biodiversity}

The 'displacement' I referenced earlier in the article is both conceptual and physical. It is physical in the sense that armed actors seeking to exploit the Pacific region's resources have forcibly displaced people from their communities:

It is important to highlight that, from the perspective of black-movement organisations and organisations of the displaced, all of the external actors - including guerrillas, paramilitaries, capitalists and the state - share the same project, namely, the appropriation of territories for the radical reconfiguration of the Pacific along the lines of the capitalist modernity project of extraction and exploitation of natural resources. This project does not coincide with the interests or reality of the black and indigenous communities. (Escobar 2003: 161)

Furthermore, this displacement is not only understood as intentional but also racist:

The Association of Displaced Afro-Colombians (AFRODES) and indigenous and black organisations see in this situation a racist strategy, and a failure of the government to protect their human and ethnic rights as stipulated in international agreements and national legislation. AfroColombians see their situation of displacement, and that of indigenous people, as unique because of, first, the uprooting of their cultural attachment to place and territory; second, the connection between mega-development projects and ethnic groups in the Pacific; third, the deleterious impact of Plan Colombia on the ethnic territories; and fourth, the long-standing situation of pervasive discrimination (ibid.: 160).

\footnotetext{
${ }^{10}$ Author interview with Benjamín Mosquera of Río Anchicayá, Buenaventura at Cali bus terminal on August 12, 2015.
} 
For instance, referencing aerial eradication in the context of unfair state policies applied to comunidades negras in the midst of the civil conflict, one gentleman publicly complained:

They came to dump all that glyphosate and we think to ourselves: It is a banned chemical but they have to exhaust it to satisfy the United States. The United States finances it, so they dump it on us in the Pacific Coast. They dump it on us blacks, on our houses. So we are punished two or three times, not just because of the war but also because of state policies. ${ }^{11}$

In mentioning "on us blacks, on our houses", this man also expresses the common perception that aerial eradication intentionally targeted black bodies and comunidades negras. "They" references the Colombian government, which is perceived as submissive to the will of US influence.

This displacement is conceptual in the sense that the PCN understands human beings and their traditions as part of a biodiverse, multicultural Colombian nation. In his study of forest policy in British Columbia, Bruce Braun (2002) utilizes the term technologies of displacement to explain how forest management experts situate the temperate forest within geographies of 'the nation', 'the market', and 'the global biosphere.' In positioning the temperate forest as a domain separate from the cultural geographies of native communities already inhabiting the forest, new actors have been authorized to "speak for the forest" (2002: 32). Likewise, the imagination of 'biodiversity' as something separate from the people and traditions of the Pacific region of Colombia displaces biodiversity into "systems of meaning, production, and exchange that have no intrinsic relation" to the "underlying ecological order" and authorizes outsiders to define biodiversity (ibid.: 35).

\section{The cultural repercussions of coca cultivation and eradication}

Thus, building upon the idea that humans and their traditions are part of the biodiversity of their environs, the PCN leaders I interviewed actively discouraged the cultivation of coca because this activity threatens those traditions and therefore the very fabric of these communities. I asked a community council leader named Daniel whether he believed the introduction of coca cultivation changed his community's relationship to the land. He argued that, fundamentally, it did not. Whether growing plantains for subsistence or coca leaf for profit, the Earth is providing for the community, albeit on a more lucrative scale for coca leaf. I was initially surprised by his response, which seemed to contradict the more common reaction from PCN leadership that coca cultivation was a threat to comunidades negras. Daniel countered that what had dramatically changed was people's relationships to each other:

Before it was not like that, it was more minga (collective effort). Someone would say, "I have a plot of land that is too big for me, let's all go and work... and you can participate when you need to." There was more sharing back then. Now things are changing, not just because of the money but also because of the violence... ${ }^{12}$

On the one hand, it makes sense that there would be less collective effort with the cultivation of coca compared to legal crops if some or most in the community frowned upon this practice. On the other hand, Daniel also mentions that coca cultivation is associated with violence, which could imply a number of different

\footnotetext{
${ }^{11}$ Comments from Luis Caicedo Balanta, a resident of Rio Napi, who vented his frustrations about aerial eradication at a PCN meeting for the association of five communities in Bocas de Temuey, Guapi, on March 14, 2015. I subsequently interviewed Luis and asked his permission to post the video I recorded of his initial discourse, which can be seen here: https://contestednatures.com/guapi-cauca-ii/

${ }^{12}$ Author interview with Daniel Goez, President of the Board of the Community Council of Cajambre at PCN office in Buenaventura, Valle del Cauca, on September 9, 2015.
} 
scenarios such as people trusting each other less, being afraid to work together, or simply less present because of injury, death, or displacement. ${ }^{13}$

Furthermore, coca cultivation is a risky investment of time, energy, and resources with potentially disastrous consequences for local crops and agricultural traditions. As Colombian anthropologist María Clemencia Ramírez notes in her ethnography of aerial eradication protests in the Colombian Amazon during the 1990s, the cultivation of coca is an extremely demanding form of agriculture that requires proper attention to the spraying of fungicides and insecticides as well as the timing of fertilization and harvest (2011: 67). This is particularly problematic in regions such as the Colombian Pacific where coca cultivation detracts from subsistence agriculture, amongst other concerns. A report on the effects of aerial eradication created by a women's rights organization in Cauca states:

We reject every type of mono-crop that threatens the life and dignity of our communities. We are conscious of the fact that we live in a region with fragile ecosystems that cannot withstand those types of practices without endangering biodiversity, cultural identity and the region's economy. In that sense, we reject coca, oil palms and the practices employed for their implementation in Afro-Colombian territories. (AsoManosNegras 2008: 19)

Mono-cropping is mentioned in this context, not only because of the associated environmental degradation, but also because comunidades negras have a proud tradition of mixing a wide variety of crops on the same plot.

While small-scale plots and the intermixing of different crops (sustenance and cash crops) are the norm for the region, eradication officials are quick to point out that this practice also makes illicit crops more difficult to detect. Article 1 of Colombian Resolution 13 of 2003 establishes, "Areas with illicit crops interspersed and/or mixed with licit crops, which correspond to cultivation strategies employed to evade action on the part of the aerial eradication program (PECIG), also will be subject to aerial eradication." Raúl of El Tambo, Cauca complained that growing illegal plants not only puts one's own legal crops in danger of being fumigated, but the entire communities' crops and homes as well. ${ }^{14}$ Therefore, even the threat of aerial eradication escalated tensions between those growing coca and those not growing coca, fostering distrust amongst neighbors.

This was particularly the case, not only because of food security, but also because aerial eradication impacted employment opportunities with serious implications for communities already economically stressed by the civil conflict. For instance, many of the farmers I interviewed hired peones (laborers) to clean unwanted foliage or to assist with planting or harvests, tasks typically performed by young men in need of work. A report created for a collective action suit for damages caused by aerial eradication in Guapi and nearby Timbiquí explains how this strategy impacted employment opportunities with far-reaching social implications:

This forced people to abandon their lots and in many places there was not any work left for laborers... While those that could not, wander in search of opportunities. In this landscape, young women and men are easily recruited by the illegal armed groups present in the region; so many of them end up joining their ranks and, almost always, these women end up becoming mothers at a young age, single and hopeless, exacerbating the already difficult conditions that they live in. (Impactos 2011: 47-48)

The shortage of employment opportunities not only leaves residents vulnerable to recruitment by non-state armed groups but also vulnerable to participate in unlawful forms of economic activity such as coca cultivation, drug trafficking, or illegal mining.

\footnotetext{
${ }^{13}$ One such form of violence is the arrival of outsiders that threaten residents of comunidades negras by taking over communal lands (Huezo 2017).

${ }^{14}$ Author interview with Raúl Figueroa of El Tambo, Cauca at Encuentro AfroPazífico in Piendamó, Cauca on August 27, 2015.
} 
The influx of income generated by these illicit activities, combined with the influence of non-state armed actors, has facilitated the conditions for conspicuous consumption and prostitution. Daniel describes how these circumstances impacted his community in Río Cajambre:

We started to see motorboats that we have never seen before, motorboats with big motors...huge quantities of alcohol...prostitution. Not that kind of prostitution where you go to a place and there are prostitutes, but that kind of hidden prostitution where the girls do favors to resolve things...in order to be invited to parties or have things paid for. ${ }^{15}$

Nemesio of Río Guajuí, Guapi, lamented that many men engaged in coca cultivation or illegal mining "lose their way", thinking themselves better than others because of the money they have made, mistreating family and community members as a result. ${ }^{16}$

Yolanda García, a prominent PCN leader and founder of AsoManosNegras explained that women, who she described as the guardians of cultural traditions, are the most impacted by the cultivation of coca and aerial eradication:

The repercussions for women are much more...double or triple the repercussions of men from the same community; in what sense? The woman in the Pacific is the bearer and protector of culture. She is the one that transmits traditional knowledge from generation to generation... that has always been the responsibility of women. ${ }^{17}$

In the role of bearer and protector of culture women not only nourish their families by preparing most of the food but also educate children in the cosmology of the region, the various rites associated with stages of life (i.e., birth, adulthood, death), and the folkloric songs and dances associated with those rites.

Yolanda's testimony speaks to the differential gendered impacts of coca cultivation and aerial eradication, which in some ways are analogous to anthropologist Donny Meertens's observations about forcible displacement in Colombia. To begin, Meertens cites two important ways that life is experienced differently for women than men in traditional rural communities: 1) rural women have less social and geographic mobility and 2) rural women typically have lower participation in civic or communal organizations in comparison to men but higher participation in "close, informal networks of neighbours and kin" (2001: 140). In terms of coca cultivation and aerial eradication, it is important to remember that these activities not only contributed to the physical displacement of individuals, families, and communities, but also to the disruption of the spaces where people interact with each other.

For example, Yolanda also reasoned that women were the most impacted by aerial eradication because they perform many daily activities uniquely connected to water:

Nowadays in our communities we do not have aqueducts as they do in other places. So we do everything at the river: fill up containers for water to make food, wash clothes, bathe...everything. And us women of the Pacific have that daily connection with the river. So they fumigate the river and logically, we are the ones most affected. ${ }^{18}$

\footnotetext{
${ }^{15}$ Author interview with Daniel Goez on September 9, 2015.

${ }^{16}$ Author interview with Nemesio Hurtado Torres of Río Guajuí, Cauca at Encuentro AfroPazífico in Piendamó, Cauca on July 28, 2015.

${ }^{17}$ Author interview with Yolanda García on August 16, 2015.

18 ibid.
} 
Thus, aerial eradication both made the river unsafe and disrupted an important space where 'informal networks of neighbors and kin gather'. The collective action suit report for the communities of Timbiquí and Guapi describes how many people reacted the first time they saw aerial eradication:

Many people, mostly women and children, not knowing the seriousness and toxicity of the substance falling on them, happily went outside to observe, for the first time, the novelty of the airplanes flying close by their homes and crops, discharging what they called "white rain" and this toxic mixture landed directly on a lot of these people. (Impactos 2011: 40)

Yolanda explained that not only were outdoor activities disrupted by aerial eradication but that women in her community attributed birth defects to the spraying. She cited the example of a stillbirth baby that emerged with enlarged skull and lips in Boca de Patía, Timbiquí. Community members claimed that the woman had been washing clothes in the river when fumigation planes sprayed. This was certainly not the only example of birth defects I heard about while conducting interviews. For instance, Nemesio of Río Guajuí attributed the birth of a child without a rectum to aerial eradication. ${ }^{19}$ While I cannot confirm that these birth defects happened or that they were caused by aerial eradication, the point of mentioning these anecdotes is to signal that aerial eradication was not only perceived as an imposition that disrupted the re-creation of culture, but also the re-creation of life itself within the territory. ${ }^{20}$ Those determining the credibility of such claims were often skeptical, at best, of the collection of evidence.

\section{Hierarchies of credibility}

US and Colombian authorities highlighted the environmental impacts of coca cultivation and processing coca in order to deflect criticism of the aerial eradication program. The focus on these concerns also contradicted unfavorable scientific findings. The Bureau of International Narcotics and Law Enforcement Affairs (INL) consistently maintained that there was no evidence that aerial eradication with glyphosate was harmful to humans or the environment. Studies that stated the contrary were rejected for three major reasons: 1) the scientists conducting said studies did not have access to the exact mixture of chemicals employed during aerial eradication operations; 2) the studies conducted in the field ignored the fact that it was impossible to separate the damages caused by coca cultivation and cocaine-processing laboratories from the damages caused by aerial fumigation; and 3) none of the studies in question had ever been subject to the peer review process. For instance, INL officials rejected the validity of an econometric study, which separates the effects of aerial eradication from the chemicals used in coca cultivation and cocaine processing laboratories on the Colombia-Ecuadorian border (Camacho and Mejía 2015), on the grounds that the article was not peer reviewed. ${ }^{21}$ Even after the Colombian Ministry of Health deemed glyphosate "likely carcinogenic" in May of 2015, the INL remained steadfast that there had never been a single case of health problems proven to be caused by glyphosate. ${ }^{22}$

In her ethnography of US policymaking in Colombia, Tate mentions 'credibility' as an epistemological category of study in anthropology that functions "as a form of social capital involving not only accuracy but also institutional origins, qualities, and larger political agendas" (2015: 64). She then discusses the 'hierarchies of credibility' that the US government employed to determine what sources of information were more reliable than others. For instance, "The US government considered Colombian government agencies to be inherently more credible than NGOs. Among the NGOS, the hierarchy of credibility was as follows: international over

\footnotetext{
${ }^{19}$ Author interview with Nemesio Hurtado Torres on July 28, 2015.

${ }^{20}$ One quantitative study, also discussed in the next section, separated the effects of aerial eradication from coca cultivation, "Our findings coincide with the medical literature and robustly indicate that aerial spraying of Glyphosate increases the probability of having dermatological and respiratory problems and miscarriages" (Camacho and Mejía 2015: 3). See also Chaves-Agudelo, Batterbury and Beilin 2015).

${ }^{21}$ Daniel Mejía is a distinguished professor of Economics and the director of the Center for Studies of Security and Drugs (CESED) at La Universidad de los Andes.

${ }^{22}$ Author interview with INL officials at US Embassy on August 4, 2015.
} 
national groups, national groups over regional ones, and professionally run over volunteer led" (ibid.). For instance, a 2014 report by the Diocese of Tumaco, Nariño estimates that, on average, every hectare of coca destroyed by aerial eradication destroys 20 hectares of forest or crops in the region (pp.31-33). However, this report and others that I gathered during fieldwork would rank at the bottom end of the hierarchy that Tate outlines and therefore carry little weight in the eyes of US policymakers.

Likewise, PCN leaders were frustrated that locally generated documentation of the impacts of aerial eradication mattered little to the Colombian government officials they had met with. While sifting through evidence for an aerial eradication court case (discussed in the next section), I encountered a 2008 report on the effects of aerial eradication in Timbiquí, Cauca. I asked Yolanda García -whose organization created the report—how government officials reacted to the information:

I remember testifying in front of a judge about the effects of aerial fumigation in Cauca and all the officials were there... from the military, to the Ministry of Health... all of the government ministries were there. And they insisted on knowing how I, an ordinary resident of the Pacific, would know that aerial fumigation with that liquid, that they denied was glyphosate, was having such and such effect, causing such and such damage in the communities when there was not any evidence. I remember telling them about a child born with deformities that tested for high levels of chemicals and an older gentleman that passed away from exposure to glyphosate... The purpose of our report was to make these problems visible but they did not take it into account in any of their own reports. I know this because, yes, we did make sure that all of the institutions received our report... Yet when I was there in front of the judge...they denied knowing anything about our report and then said that it did not meet the standards of technical validity. I guess they only accept the studies from the big time academic scholar, contracted by Harvard, and so forth...so our reports were not valid. ${ }^{23}$

The report - the first of a series developed in conjunction with the Regional Autonomous Corporation of Cauca (CRC), ${ }^{24}$ the respective community councils of Guapi and Timbiquí, and the Institute for Environmental Research in the Pacific (IIAP) - consisted of 833 surveys, 36 interviews, and visits to 17 different parcels of land (AsoManosNegra 2008). In other words, much effort was put forth into a study that was not taken seriously according to Yolanda's account. This particular example was by no means exceptional and further contributed to the perception that local knowledge was not valued in the Colombian legal system, particularly with regard to the rights of comunidades negras.

Legal victories in the case of the comunidades negras of Anchicayá in Valle del Cauca versus the Pacific Energy Company (EPSA) and the Autonomous Corporation of the Cauca Valley (CVC), however, have offered a sliver of hope that this dynamic might improve. In 2001 EPSA opened the gates of the Anchicayá dam, which released an estimated 50,000 $\mathrm{m}^{3}$ of sediment that polluted waterways, killed marine life, and ruined crops (Velasco 2016: 707). In 2009 the Superior Tribunal court of Buenaventura ordered EPSA and the CVC to pay the plaintiffs, which totaled 6000+ residents of these communities, a US\$83 billion settlement (ibid.: 716). However, this victory was short-lived as the verdict was appealed and a constitutional court overturned the ruling in 2012. In a situation reminiscent of Yolanda's experience testifying against the aerial eradication program, "The court's environmental jurisprudence gave preferential treatment to the company's rights to due process and sidestepped the collective legal and political rights of a historically marginalised community whose intermediaries could not reasonably offer the technical and scientific evidence favoured by the courts" (ibid.: 709). The 2012 decision was repealed in 2015 and the plaintiffs were to receive payment fourteen years later, thanks to the support of the Colombian Attorney General, La Defensoría del Pueblo, and a number of international organizations. Though the community is still awaiting payment as of 2018, Germán Ospina, the

${ }^{23}$ Author interview with Yolanda García on August 16, 2015.

${ }^{24}$ Regional Autonomous Corporations are decentralized environmental management authorities in Colombia and serve as the principal environmental authority at the regional level. These institutions also coordinate economic stimulus plans that map the development of municipalities in each respective department. 
lawyer for the case, credits his partnership with international NGOs such as Earth Economics for providing the kind of evidence necessary to win such a case.

\section{Validating local evidence}

When Germán invited me to participate in his latest collective action case - in which he is representing seven municipalities in the Department of Cauca suing DIRAN for damages caused by aerial fumigation, including the comunidades negras of Guapi and Timbiquí - he indicated that he again collaborated with Earth Economics to employ a similar methodology in the collection of data. This involved personally traveling to community after community over a span of several years, accompanied by a researcher from Earth Economics, to conduct interviews and administrate surveys. While reviewing the case evidence at the courthouse in Popayán I encountered dozens of binders that listed estimates for the 27,000+ residents represented in the case.

In Germán's opinion, this methodology is uniquely suited to properly compensate the victims for two major reasons: 1) These calculations ascribe an aura of technical validity -in the form of "X damaged, with a market price of $Y$ ", conducted by a trained statistician - that rivals the mountain of logistical evidence presented on behalf of the defense. 2) The calculations not only assess values to the damages incurred on individual properties (e.g. cash crops, farm animals...etc.) but also to the loss of utility of communal spaces (e.g., rivers, estuaries, forests, creeks...etc.) where day-to-day activities are conducted (e.g., fishing, gathering wood, bathing, traveling along waterways...etc.). Germán signals the importance of including the value of those communal spaces, which would normally be overlooked by a Colombian justice system disconnected from the circumstances of poor rural communities, as the most comprehensive approach to assessing the totality of the damages caused. ${ }^{25}$

This collective action case also poses some challenging questions about the intersection of state politics, legal systems and local epistemologies. As Velasco, who conducted ethnographic research on the Anchicayá dam case, notes, "if Colombia adapted multiculturalism as a principle, courts must carefully balance different types of evidence when deciding on the fundamental rights of historically marginalized and currently discriminated peoples" (2016: 725). 'What counts as evidence?' and 'How is that evidence collected?' become important questions if that assertion is to be taken seriously. These questions are certainly important to the traditions of ethnic communities and the interpretation of a Colombian constitution that "recognizes and protects the ethnic and cultural diversity of the nation" (Constitución 1991).

\section{Difference and political ecology}

This article began by explaining that many residents of comunidades negras, especially PCN leaders, viewed aerial eradication as an intentional means of displacing their communities. This perspective was articulated through a political ecology of difference framework that emphasized that comunidades negras are intrinsic to the region's biodiversity and not merely in the capacity of 'guardians of the environment.' In this particular sense, the political ecology of difference resonates with the work of political ecologists who problematize rendering humans invisible in natural spaces (Cronon 1995; Harvey 1996; Smith 1984) as well as the designation of natural spaces to the detriment of local populations (Braun 2002; Kosek 2006; Mathews 2011; Neumann 1998). The fact that aerial eradication was posited as a form of environmental conservation then begs the question: if comunidades negras are not part and parcel of the region's biodiversity, then who are they protecting this biodiversity for?

While Escobar's scholarship on the political ecology of difference often oversells the extent to which this framework encompasses the politics of all Afro-descendants of the Pacific region of Colombia, conversely, this scholarship undersells the extent to which this framework operates through difference and not just in opposition to external forces of modernity. The cultivation of coca is one such example where, despite the fact that the vast majority of PCN members I spoke with are outwardly against this activity, it is not necessarily an opposition to the community members that cultivated the plant or the act of cultivating it, or the economic

\footnotetext{
${ }^{25}$ Author interview with Germán Ospina at courthouse in Popayán, Cauca on August 19, 2015.
} 
benefits achieved by its sale. ${ }^{26}$ Rather the conversation about coca cultivation is an ongoing effort to prevent a shift in culture that disrupts people's relationships to each other and their surroundings.

Yet proving that aerial eradication - an activity beyond the control of the comunidades negras - is indeed harmful to humans, flora, fauna, and their ecosystems has been a nearly impossible task given US and Colombian drug policy officials' rhetoric to the contrary. As Oslender complains, "How pathetic the state that issues legislation obliging black communities to 'protect and conserve the species of fauna and wild flora threatened or in danger of extinction' (Law 70, Chapter 4, Article 21) and then goes and fumigates forests, lands, and rivers, pushing these species closer to extinction" (2016: 171). The 'aerial eradication as environmental conservation' discourse served two major purposes that mask the contradiction Oslender signals in his statement: 1) to further criminalize the cultivation coca, an activity already constructed as a threat to various forms of security, which was then articulated as a threat to "the environment" and 2) to shift attention from the ecological effects of aerial eradication to the ecological impacts of coca cultivation and the processing of coca paste. In addition to fighting the perception that the effects of aerial eradication are negligible and inconsequential in comparison to the harm done by coca cultivation, these communities have extremely limited means to wage such battles and are disadvantaged within the 'hierarchies of credibility' that determine justice (Tate 2015).

\section{Conclusion}

Political ecologists, hailing from a variety of academic disciplines, are uniquely situated to challenge such hierarchies. In the first place, political ecologists are equipped to deconstruct universal ecological terms biodiversity, environment, tropical hotspots...etc. - that displace humans and their cultures from their surroundings. Secondly, political ecology research can advocate for reforms in the way socio-environmental justice is carried out, specifically what should count as evidence in court systems. Lastly, political ecologists are part of the hierarchy itself and have opportunities to help flatten these relationships of power by actively collaborating in the validation of alternative ecologies.

The 2015 suspension of the aerial eradication program was lauded as a victory for socio-environmental rights in Colombia but perhaps it will be short-lived. With coca cultivation at all-time high in Colombia and both US and Colombian policymakers anxious to address the situation, aerial eradication drones are viewed as a solution that will reduce the margin of error associated with human-piloted aircraft (Felbab-Brown 2018). In the meanwhile, comunidades negras and other rural Colombian communities embroiled in the war on drugs will continue to resist this "chemical warfare".

\section{References}

Adams, W., R. Aveling, D. Brockington, B. Dickson, J. Elliott, J. Hutton, D. Roe, B. Vira and W. Wolmer. 2004. Biodiversity Conservation and the Eradication of Poverty. Science 306 (5699): 1146.

Asher, K. and D. Ojeda. 2009. Producing nature and making the state: ordenamiento territorial in the Pacific lowlands of Colombia. Geoforum 40(3): 292-302.

Asher, K. and J. Wainwright. 2019. After post-development: on capitalism, difference, and representation. Antipode 51(1): 25-44.

AsoManosNegra. 2008. Informe de Aso Manos Negra sobre la campaña adelantada en Consejos Comunitarios de Guapi y Timbiquí para evaluar los efectos generados por las fumigaciones en territorios colectivos de las comunidades negras del Pacífico caucano.

Blaikie, P.M. and S. Jeanrenaud. 1996. Biodiversity and human welfare. Geneva: UNRISD (United Nations Research Institute for Social Development).

Braun, B. 2002. The intemperate rainforest: nature, culture, and power on Canada's west coast. Minneapolis: University of Minnesota Press.

\footnotetext{
${ }^{26}$ In fact, it was through the PCN that I interviewed community members that had cultivated coca (see Huezo 2017).
} 
Camacho, A. and D. Mejía. 2015. Consecuencias de la aspersión aérea en la salud: evidencia desde el caso colombiano. CEDE.

Cárdenas R. 2012. Green multiculturalism: articulations of ethnic and environmental politics in a Colombian 'black community'. Journal of Peasant Studies 39(2): 309-333.

Chaves-Agudelo, J.M., S.P.J. Batterbury and R.Beilin. 2015. "We live from mother nature": neoliberal globalization, commodification, the 'war on drugs', and biodiversity in Colombia since the 1990s. Sage Open 5(3): 1-15.

Colombia. Policia Nacional, R. Palomino López, R. and J. Roa Castañeda. 2014. Coca deforestación contaminación y pobreza. Bogotá: Imprenta Nacional.

Constitución Política De Colombia de 1991. Accessed March 7, 2019. http://www.corteconstitucional.gov.co/inicio/Constitucion\%20politica\%20de\%20Colombia.pdf

Cronon, W. 1995. Uncommon ground: toward reinventing nature. New York: W.W. Norton.

Dawson T.P., S.T. Jackson, J.I. House, I.C. Prentice and G.M. Mace. 2011. Beyond predictions: biodiversity conservation in a changing climate. Science 332(6025): 53-58.

Díaz S., J. Fargione, F.S. Chapin 3rd and D. Tilman. 2006. Biodiversity loss threatens human well-being. PLoS Biology 4(8): 1300-1305.

Diócesis de Tumaco. Qué nadie diga que no pasa nada! Una mirada desde la Región del Pacífico Nariñense. Balance No.4. septiembre de 2014.

Dirección de Antinarcóticos. Policía Nacional de Colombia (DIRAN). http://www.policia.gov.co/portal/page/portal/UNIDADES_POLICIALES/DireccionestipoOperativas/ Direccion_de_Antinarcoticos. Accessed June 16, 2015.

Escobar, A. 2003. Displacement, development, and modernity in the Colombian Pacific. International Social Science Journal 55(1): 157-167.

Escobar, A. 2008. Territories of difference: place, movements, life, redes. Durham: Duke University Press.

Escobar, A. 1998. Whose knowledge, whose nature? Biodiversity conservation and the political ecology of social movements. Journal of Political Ecology 5: 53-82.

Felbab-Brown, V. 2018. Can Colombia eradicate coca by drones? The illusion of a technological fix. Brookings.edu. July 25, 2018. https://www.brookings.edu/blog/order-from-chaos/2018/07/24/cancolombia-eradicate-coca-by-drones-the-illusion-of-a-technological-fix/. Accessed September 14, 2018.

Forsyth, T.J.. 2003. Critical political ecology: the politics of environmental science. London: Routledge.

Grueso L., C. Rosero and A. Escobar. 2003. The process of black community organizing in the Southern Pacific Coast region of Colombia. In Gutmann, M.C. (ed.). Perspectives on Las Américas: a reader in culture, history, and representation. Malden, MA: Blackwell.

Harvey, D. 1996. Justice, nature, and the geography of difference. Oxford: Blackwell.

Impactos de las aspersiones aéreas con glifosato en los municipios de Guapi y Timbiquí, en el Departamento del Cauca. 2011. Volumen I. Popayán, Cauca.

Huezo, A. 2017. Eradication without prior consultation: the aerial fumigation of coca in the black communities of the Colombian Pacific. Canadian Journal of Latin American and Caribbean Studies / Revue Canadienne Des Études Latino-Américaines Et Caraïbes 42: 375-399.

Kosek, J. 2006. Understories: the political life of forests in northern New Mexico. Durham: Duke University Press.

Martínez-Alier, J. 2002. The environmentalism of the poor: a study of ecological conflicts and valuation. Northhampton, MA: Edward Elgar.

Mathews, A. 2011. Instituting nature authority, expertise, and power in Mexican forests. Cambridge, MA: MIT Press.

Meertens, D. 2001. The nostalgic future: terror, displacement and gender in Colombia. In Moser, C. and F. Clark (eds.). Victims, perpetrators or actors? Gender, armed conflict and political violence. London: Zed Books. Pp. 133-148. 
Myers, N. and R. Mittermeier. 2000. Biodiversity hotspots for conservation priorities. Nature 403 (6772): $853-$ 858.

Naeem, S. 2013. Biodiversity, ecosystem functioning, and human wellbeing: an ecological and economic perspective. New York: Oxford University Press.

Neumann, R. 1998. Imposing wilderness: struggles over livelihood and nature preservation in Africa. Berkeley: University of California Press.

New Annual Data Released by White House Drug Policy Office Shows Record High Cocaine Cultivation and Production in Colombia. 2018. The White House. June 28, 2018. Accessed July 16, 2018. https://www. whitehouse.gov/briefings-statements/new-annual-data-released-white-house-drug-policyoffice-shows-record-high-cocaine-cultivation-production-colombia/.

Ogden, L. 2011. Swamplife: people, gators, and mangroves entangled in the Everglades. Minneapolis, MN: University of Minnesota Press.

Oslender, U. 2008. Another history of violence: the production of 'geographies of terror' in Colombia's Pacific Coast Region. Latin American Perspectives. 35(5): 77-102.

Oslender, U. 2016. The geographies of social movements Afro-Colombian mobilization and the aquatic space. Durham: Duke University Press.

Peet, R., and M.J. Watts. 2004. Liberating political ecology. In Peet, R., and M.J. Watts (eds). Liberation ecologies: environment, development, social movements. London: Routledge. Pp. 1-47.

Porto-Gonçalves, C.W. and E. Leff. 2012. Political ecology in Latin America: natures social reappropriation and the reinvention of territories. Revista Internacional Interdisciplinary INTER thesis. 9(1): 16-50.

Ramírez, M. C. 2011. Between the guerrillas and the state: the cocalero movement, citizenship, and identity in the Colombian Amazon. Durham, NC: Duke University Press.

Reid W.V. 1998. Biodiversity hotspots. Trends in Ecology and Evolution 13(7): 275-280.

Restrepo, E. 2013. Etnización de la negridad: la invención de las "comunidades negras" como grupo étnico en Colombia. Popayán, Colombia: Editorial Universidad del Cauca.

Robbins, P. 2012. Political ecology: a critical introduction. Chichester: Wiley Blackwell.

Routledge, P., J. Sundberg, M. Power, and A. Escobar. 2012. Book review symposium: Arturo Escobar (2008) Territories of Difference: Place, Movements, Life, Redes. Durham, NC: Duke University Press". Progress in Human Geography 36(1): 143-151.

Serje de la Ossa, M., A. Caja, R. Natolini, L.M. Rexach and C. Britt-Arredondo. 2007. Iron maiden landscapes: the geopolitics of Colombia's territorial conquest. South Central Review. 24(1): 37-55.

Smith, N. 1984. Uneven development: nature, capital, and the production of space. New York, NY: Blackwell.

Tate, W. 2015. Drugs, thugs, and diplomats: US policymaking in Colombia. Stanford, CA: Stanford University Press.

United States Embassy in Bogotá. Puntos claves sobre el programa de aspersión en Colombia. Accessed June 23, 2015. http://spanish.bogota.usembassy.gov.

Velasco, M. 2016. Injustice and organisation in Anchicayá, Colombia: an environmental legal case in a hydropower watershed. Local Environment 21(6): 707-729.

Wainwright, J. and T. Barnes. 2009. Nature, economy, and the space-place distinction. Environment and Planning D: Society and Space 27(6): 966-986.

World Report 2018: Rights Trends in Colombia. January 18, 2018. Human Rights Watch. https://www.hrw.org/world-report/2018/country-chapters/colombia Accessed August 10, 2018. 